\title{
Farmers' reasoning behind the uptake of agroforestry practices: evidence from multiple case-studies across Europe
}

M. Rois-Díaz ${ }^{1}$, N. Lovri ${ }^{1}$, M. Lovric ${ }^{1}$, N. Ferreiro-Domínguez ${ }^{2,4}$, M.R. Mosquera-Losada ${ }^{2}$, M. den Herder ${ }^{1}$, A. Graves ${ }^{3}$, J.H.N. Palma ${ }^{4}$, J.A. Paulo ${ }^{4}$, A. Pisanelli ${ }^{5}$, J. Smith ${ }^{6}$, G. Moreno ${ }^{7}$, S. García de Jalon ${ }^{3}$, A. Varga $^{8}$, A. Pantera ${ }^{9}$, J. Mirck $^{10}$, P.J. Burgess ${ }^{3}$

${ }^{1}$ European Forest Institute, Yliopistokatu 6, 80100 Joensuu, Finland

${ }^{2}$ Crop Production Department, Escuela Politécnica Superior de Lugo, University of Santiago de Compostela; Campus Universitario s/n, 27002 Lugo, Spain

${ }^{3}$ Cranfield University, Cranfield, UK

${ }^{4}$ Centro de Estudos Florestais, Instituto Superior de Agronomia, Universidade de Lisboa, Tapada da Ajuda, 1349-017 Lisboa, Portugal

${ }^{5}$ Institute of Agro-Environmental and Forest Biology, National Research Council, Porano, Italy

${ }^{6}$ The Organic Research Centre, Elm Farm, Hamstead Marshall, Newbury, Berkshire RG20 OHR, UK

7 Forestry School - INDEHESA, Universidad de Extremadura, Plasencia 10600, Spain

${ }^{8}$ MTA Centre for Ecological Research, Alkotmány u. 2-4, Vácrátót, 2163, Hungary

${ }^{9}$ Department of Forestry and Natural Environment Management, TEI of Central Greece, 36100 Karpenissi, Greece

${ }^{10}$ Brandenburg University of Technology, Cottbus-Senftenberg 03046 Cottbus, Germany

Corresponding author: Mercedes Rois Díaz, mercedes.rois@efi.int, +34617944260.

\begin{abstract}
Potential benefits and costs of agroforestry practices have been analysed by experts, but few studies have captured farmers' perspectives on why agroforestry might be adopted on a European scale. This study provides answers to this question, through an analysis of 183 farmer interviews in 14 case study systems in eight European countries. The study systems included high natural and cultural value agroforestry systems, silvoarable systems, high value tree systems, and silvopasture systems, as well as systems where no agroforestry practices were occurring. A mixed method approach combining quantitative and qualitative approaches was taken throughout the interviews. Narrative thematic data analysis was performed. Data collection proceeded until no new themes emerged. Within a given case study, i.e. the different systems in different European regions, this sampling was performed both for farmers who practice agroforestry and farmers who did not. Results point to a great diversity of agroforestry practices, although many of the farmers are not aware of the term or concept of agroforestry, despite implementing the practice in their own farms. While only a few farmers mentioned eligibility for direct payments in the CAP as the main reason to remove trees from their land, to avoid the reduction of the funded area, the tradition in the family or the region, learning from others, and increasing the diversification of products play the most important role in adopting or not agroforestry systems.
\end{abstract}

Keywords interviews, narrative thematic analysis, driving forces, farming 


\section{Introduction}

Europe is characterized by a predominantly rural landscape (Eurostat 2016). In 2013, there were 10.8 million farms across the EU28, working 174.4 million hectares of land (Utilised Agricultural Area or UAA), i.e. $40 \%$ of the total land area of the EU28, while the forested area of the EU is slowly increasing and covers a slightly greater proportion of the land than is used for agriculture, 42\% (Eurostat 2016). According to den Herder et al. (2017) the total area under agroforestry in the EU27 is about 15.4 million ha which is equivalent to about $3.6 \%$ of the territorial area or $8.8 \%$ of the UAA. The same authors found that Mediterranean countries such as Spain, France, Italy, Greece and Portugal have the largest absolute proportion of agroforestry.

Over the last few decades, there has been a clear pattern of rural land abandonment and migration of people from rural to urban areas (Renwick et al. 2013; Pointereau 2008; Keenleyside et al. 2010). The motivation for this movement varies between regions but a common factor is related to agricultural profitability (Breustedt and Glauben 2007). The number of farmers in Europe is declining and their average age is going up (EC 2015). Maintaining agricultural activities, particularly in low-productive areas, becomes difficult and agricultural land is abandoned, having consequences beyond the local economy (García-Ruiz and Lana-Renault 2011; Moreira and Russo 2007). To stop abandonment of rural areas, public and private support needs to be enhanced (Olper et al. 2014). Agroforestry is one of the activities that could help to stimulate rural areas by providing additional employment and financial revenue in a sustainable way (Mercer et al. 2014; Valdivia et al. 2009; Rancane et al. 2014).

However, adoption of agroforestry systems has been constrained by various environmental and socio-economic factors. To promote its uptake, it is important to understand how farmers perceive agroforestry systems and identify what the opportunities and constraints might be from their perspectives. Much research regarding farmers' perceptions of agroforestry has been undertaken in tropical countries, where the focus is on understanding local practice, opportunities for improvement, and why interventions succeed or fail (Graves et al. 2004; Barrance et al. 2003, Franzel 1999, Fischler and Wortmann 1999; Dreschel and Rech 1998). However, much less of such research exists in a European context or in the context of highly mechanised agriculture (Graves et al. 2009). What does exist has examined the use of agroforestry practices within a broad farming systems context, for example as riparian strips (Ducros and Watson 2002), hedgerows (Morris et al. 2002), windbreaks (Matthews et al. 1993), and as silvopastoral systems (McAdam et al. 1997). Such techniques have been accepted by farmers for a number of reasons, for example, because they have an obvious functional benefit (shelter for crops or animals), are existing features of the landscape (hedgerows), or because there may be limited options for the using the land for other activities (riparian strips). In a pan-European survey of farmer perceptions of silvoarable systems in England, the Netherlands, Germany, France, Spain, Italy, and Greece undertaken for the Silvoarable Agroforestry for Europe (2001-2005) project, Graves et al. (2008) reported that $86 \%$ of interviewed farmers were willing to use silvoarable systems, but only under particular conditions, the most important of which was confidence in their profitability. In the countries where the survey took place, $16 \%$ of farmers did not think there were any benefits at all from silvoarable systems; but $30 \%$, $16 \%, 11 \%$, and $7 \%$ of farmers thought there could be economic, diversification, environmental, and landscape benefits respectively (Graves et al. 2008).

Regarding the adoption of new practices, particularly long-term systems, where a new system differs substantially from existing systems, Pannel (1999) has suggested four conditions necessary for adoption: firstly, the farmer must perceive that an alternative system exists, secondly, 
perceive that it can be trialled, thirdly perceive that it is worth trialling and fourthly perceive that it meets required objectives, particularly profit. These conditions are not easily obtained and in developed countries, three major difficulties inhibit the adoption of new technologies; firstly, developing an alternative system that is more profitable than existing systems, secondly, assessing whether it is more profitable than the current system and thirdly, overcoming the farmer's uncertainty regarding the system.

The intention of the interviews was to perform a thematic analysis to address the research question: 'why is agroforestry accepted or not'? The aim was to assess which factors act for and against the adoption of agroforestry systems by European farmers, understand the knowledge the farmers have on these systems and identify the reasons why they might have removed trees from their land. The study was framed within the European project 'Agroforestry that Will Advance Rural Development' (AGFORWARD) that aims to promote agroforestry practices in Europe that will advance rural development i.e. improved competitiveness, and social and environmental enhancement.

\section{Material and methods}

\section{Materials}

An inductive approach was chosen as it is usually used in this kind of narrative analysis because it synthesizes data while facilitating a broader understanding of the data collected.

The selection of the respondents was as random as possible after stratification into two groups: farmers practicing conventional agriculture (A), and farmers practicing agroforestry (AF); and under four different categories used in the AGFORWARD project, i.e. (i) High Nature and Cultural Value farms, (ii) high value trees, (iii) arable and (iv) livestock agroforestry (Burgess et al. 2015; den Herder et al. 2017). High Nature and Cultural Value agroforestry includes traditional systems such as the dehesas and montados in Spain and Portugal, which clearly belong to the high nature value farming systems in Europe (Moreno et al. 2016; Bugalho et al. 2011). In high value tree agroforestry the main objective is growing permanent woody crops such as fruit orchards, olive groves, and nut trees. In arable and livestock agroforestry, either crop or livestock production is integrated with trees. It should be noted that these categories are not mutually exclusive. For instance high value tree agroforestry can be practiced as either an arable or a livestock system. Nevertheless, we prefer to recognise these four categories as separate systems as the farmer's objectives and the main components of the system (traditional systems delivering cultural and ecosystem services, trees producing fruits or high value wood, crop or livestock production) are different. The farmers not implementing agroforestry were selected as having a similar production sector in the same region. The farmers were recruited from lists available in agricultural extension services and where lists would not suffice, contacts from the interviewers. Interviews were performed either face-to-face or by telephone; in both situations they were asked for permission to record it.

A total of 183 interviews were performed in eight European countries: Spain, Italy, Greece, Portugal, France, Germany, UK and Hungary. The final number of interviews performed by subsystem and region is shown in Table 1 . In the case of the UK it was very difficult to get conventional farmers engaged, thus no interviews were performed with conventional farmers. In the case of Italy and Hungary, no interviews were performed with conventional farmers because of the fact that all sheep breeders raise the sheep in agroforestry systems. 
Table 1. Distribution of the sampling for performing the interviews to farmers across Europe

\begin{tabular}{|c|c|c|c|c|}
\hline Agroforestry system & Region & Country & $\begin{array}{l}\mathrm{AF} \\
\text { interviews }\end{array}$ & $\begin{array}{l}\text { A } \\
\text { interviews }\end{array}$ \\
\hline $\begin{array}{l}\text { High Nature and } \\
\text { Cultural Value }\end{array}$ & $\begin{array}{l}\text { Central Greece / Central Macedonia / } \\
\text { Chania / Western Greece (EL1) }\end{array}$ & Greece & 8 & 8 \\
\hline \multirow[t]{3}{*}{ (HNCV) } & Santarém (PT) & Portugal & 8 & 8 \\
\hline & Extremadura (ES1) & Spain & 9 & 8 \\
\hline & Brandenburg (DE) & Germany & 8 & 8 \\
\hline High value trees & England (UK1) & UK & 5 & 0 \\
\hline \multirow[t]{2}{*}{$(\mathrm{HNV})$} & Northern Ireland (UK2) & UK & 1 & 10 \\
\hline & Galicia (ES2) & Spain & 4 & 7 \\
\hline Arable agroforestry & England (UK3) & UK & 9 & 4 \\
\hline \multirow[t]{3}{*}{ (AA) } & Central Greece / Western Macedonia (EL2) & Greece & 8 & 8 \\
\hline & Brandenburg (DE) & Germany & 8 & 8 \\
\hline & Midi-Pyrenees (FR) & France & 8 & 9 \\
\hline Livestock & Galicia (ES2) & Spain & 9 & 7 \\
\hline \multirow[t]{3}{*}{ agroforestry (LA) } & Hills of Transdanubia / Great Plain (HU) & Hungary & 7 & 0 \\
\hline & Toscana (IT) & Italy & 6 & 0 \\
\hline & & & 98 & 85 \\
\hline TOTAL & & & 183 & \\
\hline
\end{tabular}

\section{Socio-economic overview of the farmers}

Several practices have been described by the agroforestry farmers interviewed; these do not cover all existing practices in Europe, but only the ones present in this study. These are High Nature and Culture Value, hedgerows, grasslands with scattered trees, montado, dehesa and other wooded pastures and grazing in dense forest. In some cases of silvopasture systems, the grazing takes place only for a few months in the year, while in many cases they practice holistic grazing all year round.

A large proportion of the farmers (86\%) were male. Over half of the farmers (62\%) considered themselves as farmers or farm managers, $7 \%$ livestock breeders, $6 \%$ farmers with a second occupation, e.g. researcher, teacher, technical advisor, consultant, business man, forest company, $5 \%$ fruit growers and the remaining $20 \%$ have other occupations as main source of income, e.g. civil servant, carpenter, consultant, metal worker, shepherd, teacher, veterinary.

With regards the level of education, half $(53 \%)$ of the farmers hold university degrees, mainly in the agricultural sciences. A $19 \%$ hold a high school degree and another $17 \%$ had only elementary studies. A small sample (3\%) was educated in a vocational school, while a similar number (3\%) did not have any formal level of education. A few farmers were reluctant to share their level of education (5\%).

On average, farmers were 48 years old, while the age range was 23-80. The number of descendants varied between none and 7 , with an average of 1.5 children.

There was a wide variation in size between the farms, ranging from very small ( $0.1 \mathrm{ha}$ ) to very large $(11,000 \mathrm{ha})$. The largest farms corresponded mainly to the 'montado' and 'dehesa' systems in Portugal and Spain, thus the standard deviation (STDEV) is rather high. There was also considerable difference in the subsidies claims, from farmers that do not apply for any subsidy to those that get subsidies for the whole farm area (Table 2). The parameter 'CAP 2007-2013 vs. total size' refers to the comparison of the size of the farm under CAP subsidies to the actual size of the farm, thus we can observe that most of the farmers claim the entire farm under the CAP (MODE $=0$ ), while the average says that not all the hectares are claimed (MEAN $=-128.34$ ). The parameter 'CAP 2014-2020 vs. CAP 2007-2013' indicates that most of the farmers claimed or are planning to claim a similar area in both periods ( $M O D E=0)$, while the trend is to increase slightly the area under subsidies (MEAN $=3.47$ ). 
Table 2. Size of the farms of the interviewed farmers and area eligible claimed under the CAP 20072013 and CAP 2014-2020

\begin{tabular}{lrrrrr}
\hline Area (ha) & MIN & MEAN & \multicolumn{1}{c}{ MAX } & \multicolumn{1}{c}{ STDEV } & MODE \\
\hline Size of the farm & 0.1 & 363.10 & 11,000 & 993.84 & 20 \\
Size eligible CAP 2007-2013 & 0 & 242.24 & 6,612 & 674.30 & 0 \\
Size eligible CAP 2014-2020 & 0 & 263.34 & 6,612 & 697.14 & 0 \\
CAP 2007-2013 vs. total size & $-4,388$ & -128.34 & 0 & 448.26 & 0 \\
CAP 2014-2020 vs. CAP 2007-2013 & -70 & 3.47 & 320 & 33.39 & 0 \\
\hline
\end{tabular}

MEAN is the average, MIN is the minimum value, MAX is the maximum value, STDEV shows the dispersion of a set of data values, MODE shows the most frequently occurring value in the range of the data.

\section{Methods}

Qualitative interviews were made with farmers implementing and not implementing agroforestry, grouped by different sub-systems across Europe, and were analysed following the inductive research methodology of thematic analysis.

This research tried to enhance generalizability by conducting a thorough job of describing the research context and the assumptions that were central to the research, however the problem remains with transferability, because the researcher who will in the future try to "transfer" the results to a different context will be responsible for making a judgment of how appropriate the transfer is (Fereday and Muir-Cochrane 2006). Transferability is considered as a preference in a research in order to assure external validity and generalizability. This research has enabled to some extent allowance of transferability by providing sufficient detail of the context of the fieldwork for a reader to be able to decide whether the prevailing environment is similar to another situation with which he or she is familiar and whether the findings can justifiably be applied to the other setting (Shenton 2004). External validity is concerned with the extent to which the findings of one study can be applied to other situations. In Firestone (1993) there is a good presentation of a similar argument, it suggests that it is the responsibility of the investigator to ensure that sufficient contextual information about the fieldwork sites is provided to enable the reader to make such a transfer. In this context the study provides enough guidance and explanation for the readers to be able to try and replicate the findings in other settings

There were two types of questions in the interviews: 'simple', or closed format questions, and 'complex' or open format questions. The 'complex' questions were the ones through which the thematic narrative was sought, given they were appropriate enough, i.e. having substantial information, for qualitative analysis. Table 3 shows the protocol of the interviews performed.

Saturation, i.e. answers starting to repeat between farmers, was observed on average after 8 interviews. In the cases where fewer interviews were performed, the causes varied from difficulties in getting the farmers involved, or that it was not possible to identify conventional farms in those regions, e.g. sheep were farmed exclusively in agroforestry land in Italy and Hungary. 
Table 3. Protocol of the interviews to the farmers across Europe.

\begin{tabular}{|c|c|}
\hline $\begin{array}{l}\text { Group of } \\
\text { questions }\end{array}$ & Question \\
\hline $\begin{array}{l}\text { 1. Farm } \\
\text { characteristics }\end{array}$ & $\begin{array}{l}\text { What do you understand by agroforestry? } \\
\text { How did you obtain the farm? } \\
\text { What is the size of your farm? } \\
\text { What is the size of your property eligible for CAP? } \\
\text { What kind of land do you have on your farm? How much? } \\
\text { Did you declare some landscape features in the previous CAP? } \\
\text { Have you removed some trees from your land in order to be eligible for subsidies? } \\
\text { Are you planning to apply any greening measures in the CAP 2014-2020? } \\
\text { Do you have a diversified production system? Do you think diversifying your } \\
\text { production is useful? } \\
\text { Do you have permanent grasslands? Are you interested in preserving them or } \\
\text { changing them into another type of land? Do they have trees on the grasslands? Is } \\
\text { there any associated problem? } \\
\text { Do you have any agroforestry practice on your farm? }\end{array}$ \\
\hline $\begin{array}{l}\text { 2. Agroforestry } \\
\text { farm } \\
\text { characteristics }\end{array}$ & $\begin{array}{l}\text { Do you describe the management of your agroforestry systems as "intensive" or } \\
\text { "extensive"? } \\
\text { Would you categorise any agroforestry systems as of either high nature and cultural } \\
\text { value, as involving fruit or high value trees, or involving arable or livestock systems? } \\
\text { When did you start agroforestry, and what is the size of the agroforesty area? } \\
\text { Why did you start using agroforestry? } \\
\text { Did you have any major problems implementing agroforestry, and if yes which kind of } \\
\text { problems? }\end{array}$ \\
\hline $\begin{array}{l}\text { 3. No } \\
\text { agroforestry }\end{array}$ & $\begin{array}{l}\text { Why did you choose to apply only conventional farming instead of combining it with } \\
\text { agroforestry? }\end{array}$ \\
\hline $\begin{array}{l}\text { 4. Perceptions on } \\
\text { agroforestry }\end{array}$ & $\begin{array}{l}\text { Please state several positive and several negative aspects of agroforestry, with } \\
\text { respect to its } \\
\text { - } \quad \text { Production aspects } \\
\text { - } \quad \text { Environmental aspects } \\
\text { - } \quad \text { Social aspects }\end{array}$ \\
\hline \multicolumn{2}{|l|}{$\begin{array}{l}\text { 5. Providing new } \\
\text { information }\end{array}$} \\
\hline $\begin{array}{l}\text { 6. New } \\
\text { perceptions on } \\
\text { agroforestry }\end{array}$ & $\begin{array}{l}\text { After the new information given, please state several positive and several negative } \\
\text { aspects of agroforestry, with respect to its } \\
\text { - Production aspects } \\
\text { - } \quad \text { Environmental aspects } \\
\text { - Social aspects } \\
\text { Would you now consider applying agroforestry practices in your farm? } \\
\text { Do you think that a specific label for this more extensive production is needed? }\end{array}$ \\
\hline $\begin{array}{l}\text { 7. Personal } \\
\text { information }\end{array}$ & $\begin{array}{l}\text { Please state your: } \\
\text { - } \quad \text { age } \\
\text { - } \text { gender } \\
\text { - } \quad \text { occupation } \\
\text { - } \quad \text { numbation } \\
\end{array}$ \\
\hline $\begin{array}{l}\text { 8. Concluding } \\
\text { questions }\end{array}$ & $\begin{array}{l}\text { Would you like to have feedback of the research? } \\
\text { Do you have some questions or comments? }\end{array}$ \\
\hline
\end{tabular}


An inductive approach on thematic narrative analysis was used for exploring the agroforestry application phenomenon, adapted from Saldana (2009). Thematic narrative analysis is useful because it synthesizes data while recognizing the contributions and facilitating broader understanding of data collected (Fereday and Muir-Cochrane 2006). Thematic analysis is one of the most common forms of analysis in qualitative research. It emphasizes pinpointing, examining, and recording patterns (or "themes") within data (Guest 2012). Themes were seen as patterns across the data sets that were important in describing the agroforestry application practices and were associated with our research question. The themes become the categories that derived from the analysis. Thematic analysis was performed through the process of coding in several phases to create emerging and meaningful patterns. The process of developing the themes divided into $A$ and $A F$ sections was the following: (i) Stage 1: Developing the code manual, (ii) Stage 2: Finding the connections between the codes, (iii) Stage 3: Summarizing data and identifying initial themes, (iv) Stage 4: Additional coding, (v) Stage 5: Connecting the codes and legitimizing themes, (vi) Stage 6: Summarizing final themes and supporting them with quotations.

Thematic narrative analysis is a categorizing strategy for qualitative data, by doing data review, making notes and sorting it into categories, adapted from Cresswell (2009). As a data analytic strategy, it helped to move the analysis from a broad reading of the data towards discovering patterns and developing themes (Cresswell 2009; Merriam 2009). This kind of interpretative analysis attempts to describe, explain and understand the lived experiences of a group of people (Charmaz 1995). The raw data in the beginning of the analysis were given conceptual labels. Each code or concept was constantly compared to all other codes to identify similarities, differences and general patterns. Themes gradually emerge and move from a low level of abstraction to become major themes, until the point they become concepts directly related to the research question (e.g. a category of reasons why is AF implemented or not, or barrier which stops the adoption of AF in a certain region). The analysis starts by the researcher listening to the recording, and marking a time frame with words that describe that period of conversation. Several elements were used simultaneously to describe a segment of the interview. This was the initial coding phase. Afterwards, the entire interview was coded in such a manner that the researcher tried to systematize the codes by producing 'categories' of codes. Each 'category' contained its explanation, called a 'memo'. This memo contained all the relevant information to describe the code. If applicable, then the researcher tried to systematize them further in even more abstract and general groups of codes. The groups of codes found did not necessarily relate to the questions within the interview protocol. They were also related to any possible themes that bring about some understanding of the research question (i.e. why is AF accepted or not). Some of them had multiple levels of codes. This number of codes, memos and categories was kept manageable, so the researcher can still be able to find logic between their connections and find the most important emerging themes.

The process of developing the themes divided in A (Agroforestry) and AF (Conventional agriculture) sections consist of the following phases:

Stage 1: Developing the code manual

Stage 2: Finding the connections between the codes

Stage 3: Summarizing data and identifying initial themes

Stage 4: Additional coding

Stage 5: Connecting the codes and legitimizing themes

Stage 6: Summarizing final themes and supporting them with quotations 
Three types of coding were performed on the data: 'initial', 'in-vivo' and 'pattern' coding:

I. 'Initial coding' refers only to condensing the data to more manageable (shorter) units that can be listed and categorized more easily in the later phases. The essence of the ideas was captured with a few words, and the transcribed text was condensed. This is quite purely inductive thematic research, meaning there were no hypotheses to test, but just iteration of the data towards new findings. In other words, as a rule there were no predefined categories.

II. 'In-vivo coding' or direct quotations for either particularly typical or unique aspects (definitions, causalities, etc.) were written down for each question. This was done during the other coding rounds.

III. 'Pattern coding' is an iterative process of categorizing the initial codes (i.e. the shortened text fragments) into relevant meta-codes and sub-codes. It identifies patterns from the condensed data, leading to a system of sub-codes to develop a set of main themes and related sub-themes, in which the researcher inserts the finding into it. Judgement by the researchers who analysed the data was applied and additional categorizations were performed where needed. Some of them were overlapping but, in all cases, they were categorized as meta-codes in general themes and sub-codes in sub-headlines. Categorization of the variables was performed at the end. Some of the 'answers' to questions were found under other topics that are not covered by the interview protocol as they were asked in questions in subsequent interviews. The definitions of codes and of their memos evolved as they progressed through the analysis.

Relevant 'in-vivo quotations' are shown between quotation marks and in italic font, followed by the country and partner recording it. When elaborating emerging themes on the questions, the acronyms used in Table 1 are used, i.e. country, partner, type of farming practice (A/AF) and type of system.

Given that the combination of qualitative and quantitative methods is encouraged (Suddaby 2006), in the interview protocol, there were also questions related to the socio-economic situation of the farmers, which were analyzed quantitatively. Though the sample and qualitative analysis of the answers has no statistical significance to allow general conclusions to be drawn, it was used to support the findings from the interviews. The open responses were analyzed qualitatively with the support of the MAXQDA 11.0 software (MAXQDA 2016). The software assists in organizing and grouping the above mentioned coding.

Thematic analysis was used for example in a study conducted by (Thiery and Snipes, 2015) and tries to explain the reasoning behind delayed treatment for injuries in farmworkers by interviewing them and then using open-ended injury narratives coding for attitudes related to injury timing and delay. Narratives arriving from the data were then compared against demographic survey attributes in order to assess contextual information and patterns linked to treatment timing. Another example is an interview study of forest consultants employed by the Swedish Forest agency (Lidskog and Löfmarck 2016), where a contextualized thematic analysis was conducted in order to obtain knowledge of forest consultants and how they perceive and handle challenges in their advisory activities regarding the implications of bringing about strategies for forest consultants and forest policy. They used thematic analysis in order to find patterns (by using open, tentative, focused and selective coding) of broad challenges experienced by the consultants in their advisory practice. As a challenge in this study, they experienced transferability of their valid and reliable results to contexts other than the studied one. 


\section{Results}

When trying to find an answer to our research question 'why agroforestry is implemented or not' we looked at different concepts and features or properties that are linked to the driving forces behind the farmers. Before finding the reasons, there was a need to interpret what was understood by the term 'agroforestry'. Once we identified the driving forces for implementing agroforestry and those for conventional agriculture, we searched also for the reasons to remove trees from the landscape, and the key barriers that the farmers face when practicing agroforestry. In brackets and italics we quote the most relevant comments from the farmers related to the explained results.

\section{Farmers' concept of agroforestry}

The most common definition by the farmers across Europe, for both agroforestry and nonagroforestry farmers, was that it is 'a combination of trees and other crops or animals'. This definition was generally accepted without providing major details, though it is recognized that variations exist between their definitions, e.g. 'trees integrated with arable land or livestock', 'trees in the fields', 'forest and agricultural productions in the same land', 'combination of forests and livestock'. Nevertheless, some farmers have shown a more comprehensive knowledge of what agroforestry is, giving more details on the concepts, e.g. including woody vegetation as one of the components, not only trees but also shrubs, in combination with agriculture (grasslands/pastures) and livestock (e.g. dehesa), obtaining revenues from different sources or products (cattle, sheep, goat milk and meat, fruit trees, timber, biomass, crops...), coming from at least one product from the understory.

'In society, agroforestry is a new word for something extremely old and large. For example, hedgerows in this country, but there are systems even older than that. They have seen evidence of stone age hill systems in Devon, UK which resemble alley cropping - Devon hedges $12 \mathrm{~m}$ apart going up a hill side. People do not recognize the extent of agroforestry at the moment e.g. reindeer farming on 10's of million ha.' (UK3_AF_LA)

Results also showed that the concept of agroforestry was not clear for many conventional farmers that do not practice agroforestry. Some farmers defined it as growing trees, others related the definition with the promotion of trees in agriculture, while others thought that it is about integrating woodlands with crops (i.e. apple rows in crops), planted forest with arable field like corn or wheat, or grazed forest. Other farmers referred only to particular practices that were familiar for them: trees planted in strips, plantation for biofuels, or as short rotation coppice. Actually, in many cases, agroforestry was a concept that had never been heard especially by conventional farmers. What was more striking was that there was a lack of awareness among the agroforestry farmers, as many of the them were not aware of the term or concept of agroforestry, despite implementing the practice in their own farms. This confirms the need to implement communication and education for farmers, advisors and policy makers concerning agroforestry issues.

\section{Driving forces for implementation of farming practices}

The interviews aimed to identify whether there were divergent or convergent reasons for both conventional and agroforestry farmers to have decided on their farming approach.

The three main drivers observed for implementing conventional farming were tradition, the lack of knowledge on agroforestry and easier management. Tradition was the main reason to continue the farming as it was inherited or that was common in the region. It was what they knew 
works, as they were exposed to that practice. They might have chosen more sustainable agricultural practices, i.e. organic farming, but they lacked knowledge on what agroforestry is, how to implement it, the technical design, and its economic viability. In relation to the lack of knowledge, most of the farmers did not consider agroforestry as an economically viable option, requiring also a higher investment for establishment and maintenance. Furthermore, they did not see any added value from the agroforestry products, considering that there was no demand in the market for agroforestry products and that the crop production would be reduced if trees were present.

Farmers used to choose practices that receive subsidies, although they were not aware of the subsidies for agroforestry, which, in any case, are rather limited.

Conventional agriculture was also considered easier to manage, and better known. Farmers perceived that management issues are the main constraints to limit agroforestry adoption. Some of the farmers also considered that having animals makes it more complicated for having to find feed for the animals during winter, trees complicate mechanization and sometimes trees are not compatible with grazing. For instance, in grazed apple orchards animals had to be taken out of the system during several months because of spraying with herbicides. Thus providing an area for the animals during these months can be difficult for many farmers.

\section{'Mechanization was the main reason not to put trees.' (FR_A_AA)}

Presence of trees on arable lands obstructs mechanization and for this reason trees were removed from rural landscape since industrial agriculture was adopted in more intensive agricultural areas. Some farmers considered that agroforestry needs more time dedication, that there is more work to be done and they lack the time and human resources to work on the farm, confirming that agroforestry systems are complex systems that require specific technical skills. If the plots are small, farmers did not consider other farming options as profitable, at least with the current CAP payment scheme. On the other hand, high quality soil is a scarce resource to be maximized, thus many farmers having a very productive soil preferred to maximize its production and use it only for agriculture. They considered that if trees occupy very valuable land, an expensive resource, agroforestry then becomes for them an opportunity cost.

'Land is a very valuable scarce resource, for which the production must be maximized, especially if it is a high-quality soil, or if the plots are small.' (DE_A_HNVC)

Another driving factor influencing the type of farming was the farmer age. Farmers that were close to retirement were not interested in new types of farming and would keep doing what they have done their whole life. Young farmers were more interested in introducing innovative practices (García de Jalón et al. 2013). Ownership of the land was also a limitation, as farmers that rent the land cannot introduce trees as the owners do not usually want to plant any trees.

Interestingly, many farmers were interested in the agroforestry practices introduced by the interviewers and considered giving it a try after the interviews, but would need to see examples that those practices are profitable to decide to invest in those, and see other advantages.

Moving into the agroforestry farmers' vision, many different reasons were identified by the different farmers in deciding to implement agroforestry, while the three main drivers were tradition, diversification of the products and learning from others. Again, similar to conventional farmers, the tradition in the family or in the region, influenced the decision of most of the farmers to continue with the existing traditional agroforestry system. Behind that, there are cultural reasons and the acknowledgment of the benefit of the synergies between the different components. Agroforestry 
provides a diversification of products (wood, fodder, meat, milk, crops), which contributes to increase the production and the profitability of the farm with several lines of income, maximizing revenues and reducing some costs e.g. associated with land clearing. Agroforestry produces fodder for the animals in winter time and pastureland instead of useless dense shrubs. Furthermore, products obtained in agroforestry were always identified as high quality products. The diversification of products and synergies among the components (trees, animals and crops) was valued as decreasing the risks in crop production due to weather events or market changes.

'Pastures without trees are more vulnerable to weather conditions.' (PT_AF_HNCV)

Learning from others and seeing the benefits was an encouraging driver to implementing agroforestry practices. Sources of learning were varied: attending a meeting, working abroad, colleagues or other farmer experiences, internet, etc. Also research initiatives led to new agroforestry farms, as farmers were contacted for research purposes and their farms used as demonstration plots.

Unproductive soils do not provide significant crop production, and small fields in difficult areas are hard to manage, thus agroforestry became an alternative in marginal lands, which at the same time improves soil condition (fertility) and increases biomass production. Under this point of view, in many marginal areas agroforestry systems are relevant for keeping a human presence in most remote areas by providing a low but sustainable source of income. In many marginal areas intensive agriculture was not possible due to limiting factors (poor soils, slope morphology) and in these conditions agroforestry can be a valuable alternative. Thus, agroforestry offers a sustainable alternative that can lead to a reduction in rural land abandonment.

'The silvopastoral system was introduced because arable crops are not convenient, due to the poor production, in marginal lands.' (IT_AF_SP)

Agroforestry improved the environment around the farm, hedgerows protect from wind and water erosion, animals decrease the risk of forest fires (with associated cost reduction for land clearing), provides shelter for animals and birds, is good for the environment and nature conservation in general, including a solution for the pollination of trees. Hedgerows, for instance, protected from wind and water erosion, animals decreased the risk of forest fires, with associated cost reduction for land clearing

'I started to combine apple trees with bees to increase pollination because the trees had pollination problems.' (ES2_AF_HNV)

Agroforestry had a high aesthetics value for the farmers, and because of their different components, it was considered as a nice landscape and as part of the cultural heritage. Some agroforestry systems may result in more tourism in rural areas and more rural employment, thus motivating farmers. Some aware farmers defended animal welfare (less stress, better quality feed) as a priority, e.g. poultry grow in their natural environment and lambs receive shelter in their first days. For instance, silvopastoral systems increase animal welfare, especially in Mediterranean hot summers where trees provide shade to animals.

Agroforestry was considered as a complex system that provides a more efficient management of resources and increases sustainable eco-intensification. Sustainable production was given priority over conventional agriculture when it was a second occupation, and not the primary source of income, given that it might not be as productive as conventional farming, chosen when 
there was pressure to make profit. Agroforestry perfectly matched the need to promote multifunctional agriculture as stated by the main international agreements and institutions.

Subsidies were also an incentive to apply agroforestry, to ensure the farms were profitable. Furthermore, different laws and regulations, like e.g. on hedgerows in Germany might impose restrictions on applying other practices rather than the existing ones.

'The system is historical. The hedgerows were already established 300 years ago and are protected by the law. It is not allowed that they are removed. I am an agricultural farmer and if I could I would remove them.' (DE_AF_HNCV)

To summarize the above described results, Tables 4 and 5 reflect all the driving factors identified by the farmers across the different countries in Europe.

Table 4. Drivers for practicing conventional farming

\begin{tabular}{|c|c|c|c|c|c|c|c|c|}
\hline Driving factor & FR & ES & $\mathrm{DE}$ & PT & $\mathrm{HU}$ & EL & UK & IT \\
\hline Tradition & $\bullet$ & $\bullet$ & $\bullet$ & & & & $\bullet$ & \\
\hline Lack of knowledge on AF & & $\bullet$ & $\bullet$ & $\bullet$ & & $\bullet$ & $\bullet$ & \\
\hline Profitability & & $\bullet$ & $\bullet$ & $\bullet$ & & $\bullet$ & $\bullet$ & \\
\hline Not aware of subsidies for agroforestry & & & & & & $\bullet$ & & \\
\hline Easier management & $\bullet$ & & & $\bullet$ & & $\bullet$ & $\bullet$ & \\
\hline Less time dedication & & $\bullet$ & & & & $\bullet$ & & \\
\hline Small plots & & $\bullet$ & $\bullet$ & & & $\bullet$ & $\bullet$ & \\
\hline Scarce high quality soil & & & $\bullet$ & $\bullet$ & & & & \\
\hline Age & & $\bullet$ & & & & & & \\
\hline Rented land & & & $\bullet$ & & & & & \\
\hline Willingness to try $\mathrm{AF}$ & $\bullet$ & $\bullet$ & $\bullet$ & $\bullet$ & & $\bullet$ & & \\
\hline
\end{tabular}

The symbol $\bullet$ in the cells indicate which driver was identified by the farmers in the different countries

Table 5. Drivers for practicing agroforestry

\begin{tabular}{|c|c|c|c|c|c|c|c|c|}
\hline Driving factor & FR & ES & $\mathrm{DE}$ & PT & $\mathrm{HU}$ & EL & UK & IT \\
\hline Tradition & & $\bullet$ & $\bullet$ & $\bullet$ & $\bullet$ & $\bullet$ & & $\bullet$ \\
\hline Diversification of products & & $\bullet$ & $\bullet$ & $\bullet$ & $\bullet$ & & • & \\
\hline Learning from others & & $\bullet$ & $\bullet$ & & & & $\bullet$ & \\
\hline Marginal lands & $\bullet$ & & $\bullet$ & & & & & $\bullet$ \\
\hline Improving environment & & $\bullet$ & $\bullet$ & $\bullet$ & • & & & \\
\hline Landscape coherence & $\bullet$ & & $\bullet$ & & & & & \\
\hline Aesthetics value for tourism & & & $\bullet$ & $\bullet$ & $\bullet$ & & $\bullet$ & \\
\hline Animal welfare & & $\bullet$ & & & $\bullet$ & & $\bullet$ & \\
\hline Use existing fences & & & & & & & $\bullet$ & \\
\hline Quality of life & & $\bullet$ & & & & & & \\
\hline Research purposes & & & $\bullet$ & & & & $\bullet$ & \\
\hline Sustainable eco-intensification & & & & $\bullet$ & & & $\bullet$ & \\
\hline Second occupation & & & $\bullet$ & & & & & \\
\hline Subsidies & & • & & & & & $\bullet$ & \\
\hline Regulations & & & $\bullet$ & & & & & \\
\hline
\end{tabular}

The symbol $\bullet$ in the cells indicate which driver was identified by the farmers in the different countries.

\section{Removal of trees from the landscape}

Agroforestry farmers did not see any problem having trees on grasslands, but the first reason for removing trees and shrubs was to facilitate management to establish and maintain their grasslands and having wood pasture instead of having a dense shrub land. Some obstacles that trees may generate are the difficulty of using tractors or machines for establishment and/or maintenance of the pastures due to the distance between trees, or the damage that limits tree regeneration due to 
the presence of the animals. Some farmers have removed a few fruit trees growing on the farm boundaries because they were an impediment for farm machinery. At the same time, some farmers considered the trees as a focus of diseases, and attracting birds that eat the seeds.

In order to protect cork oak roots I am not able to use disc harrow and instead have to use mounted knifes or chains. This last equipment is more restricted when wanting to renew the pastures.' (PT_AF_HNCV)

Trees have been also removed from the fields as part of tradition, or to establish a more profitable new crop, e.g. olive trees. Only a few farmers mentioned eligibility for CAP subsidies as the main reason to remove trees from their land, to avoid the reduction of the funded area. In the new CAP (2014-2020) tree densities up to 100 trees/ha is allowed without a reduction in the funded area, as the CAP recognizes the role of hedgerows and isolated trees in arable lands.

Regulations may further limit the removal of trees. In some cases, it was not allowed to remove trees in the state owned forests, the forest service did not allow any intervention, and rarely permitted any tree removal, as was the case in Greece. The hedgerows could not be removed either in Germany.

'We would gladly remove some trees growing in our grasslands which they inherent our flocks and reduce the available grazing land but we are not allowed to by the forest service.' (EL1_AF_HNCV)

In any case, in most of the interviews, both agroforestry and non-agroforestry farmers reported that they had not removed any trees from their farms on a voluntary basis.

\section{Key barriers restricting agroforestry}

When interviewing the agroforestry farmers, three major problems on the implementation of agroforestry were highlighted: problems with farm management, regulation problems and lack of knowledge. Many farmers saw some difficulties in management, as agroforestry is more difficult compared to conventional agriculture, but did not consider those as barriers. The main problem was that it was hard work to start an agroforestry farm and/or renew an abandoned area. It usually needed high economic resources and was time demanding.

Other management issues included: higher management costs of the animals, difficulties in finding a good shepherd, bureaucracy becomes a burden (land and animal registrations, land delimitation and so on), fencing from wild animals required, decay of cork oaks, natural regeneration, problems with the quality of the pastures where the cows feed because climate fluctuation makes it difficult to provide food only with pastures and frequently they have to buy additional food in the summer to feed the cows, hard to count and look after the animals in the orchards.

'I cannot invest or do anything different from what I do right now due to lack of help. People come and work only for some days and then leave.' (EL1_A_HNCV)

Wild animals (wolves, wild boars) represented another relevant management problem, which was connected to the abandonment of agricultural lands. Recently many lambs were killed, for instance in Italy. Sheep suffered stress and thus production was limited. Due to the frequent attacks, sheep were housed in barns during the night, but was not enough to prevent damages from wild fauna. On the contrary, when the wild fauna was not a problem, sheep were left in the open 
field for the whole time. Preventive measures and monitoring of wolves presence should be carried out by local public institutions.

Some farmers complained about the administrative burden and slow response from the administration for permission to establish new systems and on the CAP limitations and complexity. Moreover, not all farmers were aware of the possibility of establishing agroforestry systems in the frame of the Rural Development Programmes of the CAP.

Low profitability and product price fluctuations were also mentioned as problems, as well as low demand due to the financial crisis, together with high costs of establishment (fencing, protectors), changing to breeds more compatible with the trees, the long term required for returns (i.e. 15 years from apple trees for a good fruit production). Many farmers perceived a need to create a label for agroforestry products.

In any case, it was positive that many of the remaining farmers did not identify any problem while managing their agroforestry farms.

\section{Discussion}

The thematic narrative analysis derived from the data aimed to identify the driving forces affecting 'why agroforestry is adopted or not'. Among several reasons, the study shows that the major driving forces are tradition in the family or the region, diversification of products that agroforestry provides, and learning from successful and inspiring experiences.

There are not many studies apart from Graves et al. (2009) on the driving forces behind farmer's behaviour, as regards to agroforestry farming, at the European level, but there are some studies in particular regions or socio-economic environments (Sereke et al. 2016).

Domínguez and Shannon (2011) state that land owners manage their lands with four axes in mind: economic expectations of the property, ethical reasons, how the land should look, and natural risks. The relationship between socio-psychological factors (e.g. cultural, demographic, economic, and social variables, including ancestors, peers and education) and how people make decisions in practicing agroforestry are inseparable, and must be considered if policy makers, extension agents, and agricultural educators hope to influence and improve landowners' agroforestry management (Saha et al. 2011).

Based on the responses of the conventional farmers in this study, three major drivers for implementing conventional farming instead of agroforestry were tradition, the lack of knowledge on agroforestry and management simplicity. Nevertheless, other factors affecting the decision were economic viability, existence of subsidies, time needed for dedication, high quality soil, as well as age of the farmer and ownership of the land. Past research has shown that land ownership is frequently a barrier to adoption of innovative practices (e.g. Knowler and Bradshaw 2007; García de Jalón et al. 2015). One of the reasons for not establishing agroforestry was that when planting trees, the land would be tied up for future uses. This finding appeared as the most important factor in the study performed by Flexen et al. (2014) in Ireland, showing that farmers, both agroforesters and non-agroforesters, would consider planting trees in their plots, if there were greater financial incentives, or if they had land that was poor or unsuitable for farming (Flexen et al. 2014). A common attitude found amongst many farmers, both in our study and the previously mentioned study, was that farmers did not seem to plant trees in rich soils because of a lower farm net margin. They stated that they would only plant trees on marginal land where farming was difficult or unprofitable. Several studies examined the attitudes of UK farmers to planting farm woodlands (summarised in Doyle and Thomas, 2000). In general, these studies showed that most farmers 
viewed forestry as an inappropriate use of productive land and irrelevant as an alternative source of income, primarily because planting incentives for conventional forestry were seen as inadequate to remove land from farm production. Doyle and Thomas (2000) suggest that as agroforestry involves the diversification of existing agricultural systems, and maintains the majority of the land area in agricultural production, it should encounter less resistance from farmers. They note that a key limitation is a lack of awareness of agroforestry among farmers.

To motivate farmers to manage more complex agroecosystems that are fundamentally different to their current simplified systems is challenging (Pannell 1999). Interestingly, many farmers interviewed in this study showed interest in the agroforestry practices and considered implementing it in their farms. This reflects openness and willingness but a lack of knowledge that the farmers have on alternative farming options; they would need to see examples that those practices are profitable and have many other advantages before deciding to invest in them. In order to attract farmer interest in investing lands with agroforestry systems, local demonstration plots where agroforestry practices are tested would be worthwhile. Some farmers would implement agroforestry practices if there were economic supporting measures, if they would perceive that the management was simple and if there would be no difficulties with the landowner. For these reasons it would be beneficial to establish and/or reinforce networks among stakeholders in order to facilitate the flow of knowledge. Innovative farmers can find empirical solutions to their problems and experiment themselves with agroforestry practices.

The results in this study are in line with Saha et al. (2011) which indicate that farmers' decision-making processes were most influenced by factors such as ancestors and education, followed by peers, financial condition, and economic importance of the agroforestry land holding. The attitudes of nature conservation managers, who are actually the farmers of the protected areas, to implementing agroforestry management based on traditional ecological knowledge was determined by ancestors and childhood memories, mainly by their own experiences, and not their studies (Varga et al. 2016).

When looking at the agroforestry farmers' drivers, also tradition and learning from other experiences appeared as main reasons for implementing agroforestry, together with diversification of products, which reduces the risk in production, another relevant aspect for the farmers. These main drivers contrast with those of farmers in other European regions not included in this study, e.g. Switzerland, where the primary motivations were habitat function, both for biodiversity conservation and shade for livestock (Sereke et al. 2016). Nevertheless, animal welfare was also mentioned as an important driver among the farmers interviewed. Animal health and biodiversity also played a role in the motivations of farmers in Estonia (Roellig et al. 2015). Most farmers believed their animals thrive better in a more "natural" environment, needing less medication. In a similar study in Ireland, most of the agroforestry farmers rated landscape improvement and environmental factors as very important factors, as well as provision of shelter for livestock (Flexen et al. 2014).

The farmers in the current study considered agroforestry as a good alternative for low productivity marginal lands. Improving the environment, aesthetic value and quality of life were further reasons for implementing agroforestry. Similarly, the motivation to conserve cultural landscapes through agroforestry was lower among non-adopters in Switzerland compared to adopters (Sereke et al. 2015). Other studies in France revealed that the difficulties in accessing the land and the need to reduce agricultural inputs through functional biodiversity and diversification motivated smaller farmers to combine annual plants and fruits with the aim to increase their plot 
performance on a multifunctional basis, increasing the number of such plots significantly in the last few years (EURAF 2015).

Existing subsidies also encouraged farmers to manage the land in certain ways. Some farmers in this study chose practices that receive subsidies, although many were not aware of existing subsidies for agroforestry, which, in any case, are rather limited. The European Commission recently recognized the social and environmental value of agroforestry systems (EU Reg. 1698/2005) and a specific measure (M222) supporting agroforestry was introduced in the 2007-2013 CAP. The measure (M8.2) was improved in the 2014-2020 programming period (EU Reg. 1305/2013) and it is expected that its uptake would increase in the next few years. Furthermore, other studies have shown that the availability of grants did appear to influence those who are already interested in planting trees on the fields but not those that who are not (Lawrence et al. 2010). Roellig et al. (2015) identified in Estonia that the determining factor to encourage management or restoration of wood-pasture was financial support. On the other hand, most farmers had a clear passion for managing their land and were proud of maintaining their wood-pastures following local traditions.

Regulations, on the contrary, might limit the use of different agroforestry structures (e.g. hedges) and lands. These reasons were observed also in Switzerland with policies shifting from promoting trees or not on farms (Sereke et al. 2016). The perceived behaviour revealed that farmers felt rather free to decide whether to practice agroforestry or not, but they believed that framework conditions do not allow adoption. Environmental regulation was not a motivation, then, for both adopters and non-adopters.

Thus, although factors such as stewardship or farmer image might motivate a small number of farmers to use agroforestry systems, on a wider scale, voluntary adoption of agroforestry systems may need to be encouraged through subsidies, tax relief, or cross compliance, and compulsory adoption through government strategic plans, or penalties for non-adoption (Pannel 1999). Sereke et al. (2016) also justify subsidies for ecological production, and incentivize the local and indigenous agricultural products. Public support for land management is justified when such management provides public goods, e.g. environmental or social benefits such as rural vitality (EBCD 2012).

In order to encourage farmers to take up agroforestry, it is necessary to raise awareness among the farmers about the benefits of these practices, showing them examples of successful farms. Limited awareness of agroforestry among farmers and landowners was identified in the current study and by a number of other studies (McAdam et al. 1997; Doyle and Thomas 2000). For example, in a study by Graves et al. (2009), only 33\% of farmers correctly defined agroforestry as the integration of trees with crops or livestock systems. These studies showed, however, that when farmers were shown agroforestry systems, their level of interest increased. Farmer-led projects have greater credibility in the eyes of other farmers (the peer-to-peer effect), thus one channel for raising awareness is to update the extension services with the latest developments and findings for further knowledge transfer. It was proven by Primmer and Karppinen (2010) that technical solutions suggested by technicians from extension services are incorporated by farm owners into their decision-making. Technicians are a relevant influencing agent for the owner to decide on the different management alternatives, in particular in cases with high uncertainty and complexity, e.g. price fluctuations and climate change (Schläuter and Koch 2009). Hauck et al. (2016) indicate that at the local level, technical journals were an important source of information for farmers, advising them, for example, on the different agri-environmental schemes that were available, while linkages between farmers and all stakeholders for exchanging information are encouraged. 
There is also a clear need for raising awareness among the consumers, for them to give priority to agroforestry-derived products despite of higher prices, which in turn becomes an incentive for farmers. Duesberg et al. (2014) also recommended that, in addition to monetary incentives, policy tools such as image and information campaigns should be used. A broader knowledge about ecosystem services needs to be made available to farmers and to the society at large, to increase recognition of local ecological solutions (Sereke et al. 2016).

There are though, several limitations to the validity of the results in this study, due to wide variety of interpretations from multiple researchers doing the analysis. In addition, with thematic analysis, nuanced data could be easily missed. Furthermore, the flexibility of analysis makes it difficult to concentrate on which aspect of the data to focus on and the discovery and verification of themes and codes mixed. Finally, yet importantly, there is limited interpretive power and generalizability if analysis excludes theoretical framework (Gregg 2012), and there is a small degree to which the results of this qualitative research can be generalized or transferred to other contexts or settings.

\section{Conclusions}

The main driver for the farmers, both conventional and agroforestry, to apply conventional or agroforestry farming, was the tradition in the family or the region and to continue with the existing traditional system. Knowledge of existing successful practices was also an encouraging driver for the uptake of agroforestry practices. Interestingly, there was a lack of awareness of agroforestry, as many of the farmers were not aware of the term or concept of agroforestry, despite implementing the practice in their own farms. Furthermore, the lack of knowledge led to misconceptions or wrong assumptions, as it was observed in the perceptions the farmers have on agroforestry practices. Many farmers would be willing to implement agroforestry if they would have more knowledge on those available, their profitability, benefits and practical know-how.

Undecided farmers would like to apply or expand agroforestry in their farm if the systems would be rewarding from an economic point of view. Only a few farmers considered the eligibility of their land for existing subsidies as the main reason to remove trees from their land, to avoid the reduction of the funded area. Subsidies within the CAP should favour this type of farming with more measures, which should also be explained thoroughly and encouraged by the extension services, increasing the awareness of grants available besides the practical knowledge on management and alternatives. Raising awareness of consumers on the quality of the agroforestry products and the ecosystem services provided by the agroforestry systems is also essential for encouraging farmers to practice agroforestry.

\section{Acknowledgements}

This work was funded through the AGFORWARD Project from the European Union's Seventh Framework Programme for Research, Technological Development and Demonstration under Grant Agreement no. 613520 . The views and opinions expressed in this article are purely those of the writers and may not in any circumstances be regarded as stating an official position of the European Commission. Further, the work has also been supported by the Xunta de Galicia, Consellería de Cultura, Educación e Ordenación Universitaria (Programa de axudas á etapa posdoutoral DOG no122, 29/06/2016 p.27443, exp: ED481B 2016/071-0). The authors would like to thank the contribution from the AGFORWARD project partners involved in performing the interviews in the field and their transcription. We would like to express also our sincere gratitude to all the farmers who accepted 
dedicating part of their valuable time to the interviews. Without such contributions and commitment, the study would have not been feasible.

\section{References}

Barrance AJ, Flores L, Padilla E, Gordon JE, Schreckenberg K (2003). Trees and farming practices in the dry zone of southern Honduras I: campesino tree husbandry practices. Agroforestry Systems 59 (2): 97-106.

Breustedt G, Glauben T (2007) Driving Forces behind Exiting from Farming in Western Europe. Journal of Agricultural Economics, 58: 115-127. doi:10.1111/j.1477-9552.2007.00082.x

Bugalho MN, Caldeira MC, Pereira JS, Aronson J, Pausas JG (2011) Mediterranean cork oak savannas require human use to sustain biodiversity and ecosystem services. Front. Ecol. Environ. 9: 278-286.

Burgess PJ, Crous-Duran J, den Herder M, Dupraz C, Fagerholm N, Freese D, Garnett K, Graves AR, Hermansen JE, Liagre F, Mirck J, Moreno G, Mosquera-Losada MR, Palma JHN, Pantera A, Plieninger T, Upson M (2015) AGFORWARD Project Periodic Report: January to December 2014. Cranfield University: AGFORWARD. 95 pp. http://www.agforward.eu/index.php/en/news-reader/id-27-february2015.html.

Charmaz K (1995) Grounded Theory. In Smith, J., Harré, R., Van Langenhove, L., 1995. Rethinking Methods in Psychology. SAGE. 214 pp.

Creswell JW (2009) Research design: Qualitative, quantitative, and mixed methods approaches. Los Angeles, CA: Sage.

den Herder M, Moreno G, Mosquera-Losada MR, Palma JHN, Sidiropoulou A, Santiago-Freijanes J, Crous-Duran J, Paulo J, Tomé M, Pantera A, Papanastasis V, Mantzanas K, Pachana P, Papadopoulos A, Plieninger T, Burgess PJ (2017). Current extent and stratification of agroforestry in the European Union. Agriculture, Ecosystems and the Environment, 241: 121-132. doi:10.1016/j.agee.2017.03.005

Domínguez G, Shannon M (2011) A wish, a fear and a complaint: understanding the (dis)engagement of forest owners in forest management. European Journal of Forest Research, 130, 435-450.

Doyle C, Thomas T (2000) Chapter 10. The social implications of agroforestry. In: Hislop, A.M., Claridge, J. (Eds.), Agroforestry in the UK. Bulletin 122. Forestry Commission, Edinburgh.

Dreschel P, Rech B (1998) Composted shrub-prunings and other organic manures for smallholder farming systems in southern Rwanda. Agroforestry Systems 39(1): 1-12.

Ducros C, Watson NM (2002) Integrated land and water management in the United Kingdom: narrowing the implementation gap. Journal of Environmental Planning and Management 45(3): 403-423.

Duesberg S, Ní-Dhubháin Á, O’Connor D (2014) Assessing policy tools for encouraging farm afforestation in Ireland. Land Use Policy 38,194-203.

EBCD (2012) Agroforestry: Trees for a Sustainable European Agriculture. Report of the EP Intergroup on Climate Change, Biodiversity and Sustainable Development. https://euraf.isa.utl.pt/sites/default/files/pub/docs/report_en_0.pdf. Accessed 28 June 2016.

EC (2015) EU farms and farmers in 2013: an update. EU Agricultural and Farm Economics Briefs. Agriculture and Rural Development. http://ec.europa.eu/agriculture/sites/agriculture/files/rural-areaeconomics/briefs/pdf/009_en.pdf. Accessed 10 March 2017.

EURAF (2015) SMART Project. Agroforestry Systems associating fruits and vegetables (France). EURAF Newsletter 10, March 2015. URL: https://euraf.isa.utl.pt/newsletters/newsletter_10\#p2.4. Accessed 25 October 2016.

Eurostat (2016) Your Key to European Statistics. http://ec.europa.eu/eurostat/web/ruraldevelopment/statistics-illustrated. Accessed 23 May 2016.

Fereday J, Muir-Cochrane E (2006) Demonstrating rigor using thematic analysis: A hybrid approach of inductive and deductive Qualitative Methods, 5(1), 80-92.

Fischler M, Wortmann CS (1999) Green manures for maize-bean systems in eastern Uganda: agronomic performance and farmers' perceptions. Agroforestry Systems 47 (1/3): 123-138. 
Flexen M, McAdam JH, Anderson D (2014) A survey of attitudes of farmers in Northern Ireland to agrienvironment schemes and woodland creation. Report to DARD.

Franzel S (1999) Socio-economic factors affecting the adoption potential of improved tree fallows in Africa. Agroforestry Systems 47 (1/3): 305-321.

García de Jalón S, Iglesias A, Quiroga S, Bardají I (2013) Exploring public support for climate change adaptation policies in the Mediterranean region: A case study in Southern Spain. Environmental Science \& Policy 29, 1-11.

García de Jalón S, Silvestri S, Granados A, Iglesias A (2015) Behavioural barriers in response to climate change in agricultural communities: an example from Kenya. Regional Environmental Change 15 (5), 851-865.

García-Ruiz JM, Lana-Renault N (2011) Hydrological and erosive consequences of farmland abandonment in Europe, with special reference to the Mediterranean region-a review. Agriculture, ecosystems \& environment, 140(3), 317-338.

Graves AR, Matthews RB, Waldie K (2004) Low external input technologies for livelihood improvement in subsistence agriculture. Advances in Agronomy 82: 473-555.

Graves AR, Burgess PJ, Liagre F, Pisanelli A, Paris P, Moreno G, Bellido M, Mayus M, Postma M, Schidler B, Mantzanas K, Papanastasis VP, Dupraz, C (2008) Farmer perceptions of silvoarable systems in seven European countries. Advances in Agroforestry 6: 67-86

Graves A, Burgess P, Liagre F, Pisanelli A, Paris P, Moreno G, Bellido M, Mayus M, Postma M, Schindler B, Mantzanas K, Papanastasis VP, Dupraz C (2009) Farmer perceptions of silvoarable systems in seven European countries. In: Rigueiro-Rodríguez A, McAdam J, Mosquera-Losada MR (eds) Agroforestry in Europe. Advances in Agroforestry. Volume 6. Springer.

Guest G (2012) Applied thematic analysis. Thousand Oaks, California: Sage. p. 11.

Hauck J, Schmidt J, Werner A (2016) Using social network analysis to identify key stakeholders in agricultural biodiversity governance and related land-use decisions at regional and local level. Ecology and Society, 21(2):49. DOI:10.5751/ES-08596- 210249.

Keenleyside C, Tucker G, McConville A (2010) Farmland Abandonment in the EU: an Assessment of Trends and Prospects. Institute for European Environmental Policy, London.

Knowler D, Bradshaw B (2007) Farmers' adoption of conservation agriculture: a review and synthesis of recent research. Food Policy 32:25-48

Lawrence A, Dandy N, Urquhart J (2010) Landowner attitudes to woodland creation and management in the UK. Forest Research, Alice Holt, Farnham. http://www.forestry.gov.uk/fr/ownerattitudes. Accessed 27 September 2016.

Lidskog R, Löfmarck E (2016) Fostering a flexible forest: Challenges and strategies in the advisory practice of a deregulated forest management system, Forest Policy and Economics 62 (2016) 177-183.

McAdam J, Gazeau S, Pont F (1997) An assessment of farmer attitudes to agroforestry on sheep and cereal farms in Northern Ireland. Agroforestry Forum 8(3): 5-8.

Matthews S, Pease SM, Gordon AM, Williams PA (1993) Landowner perceptions and the adoption of agroforestry practices in southern Ontario, Canada. Agroforestry Systems 21(1): 11-25.

MAXQDA (2016) Software for qualitative data analysis, 1989-2016, VERBI Software - Consult - Sozialforschung $\mathrm{GmbH}$, Berlin, Germany.

Mercer DE, Frey GE, Cubbage FW (2014) Economics of Agroforestry. Chapter 13. In: Kant S, Alavalapati JRR (eds) Handbook of Forest Resource Economics. Earthscan from Routledge. 188-209. 22 p.

Merriam SB (2009) Qualitative research: a guide to design and implementation San Francisco, CA: Jossey-Bass.

Moreira F, Russo D (2007) Modelling the impact of agricultural abandonment and wildfires on vertebrate diversity in Mediterranean Europe. Landscape Ecology, 22(10), 1461-1476.

Moreno G, Gonzalez-Bornay G, Pulido F, Lopez-Diaz ML, Bertomeu M, Juárez E, Diaz M (2016) Exploring the causes of high biodiversity of Iberian dehesas: the importance of wood pastures and marginal habitats. Agroforestry Systems 90: 87-105. 
Morris RM, Oreszczyn SM, Sloate C, Lane AB (2002) Farmers' attitudes, perceptions and the management of field boundary vegetation on farmland. In: Frame J (ed) Conservation pays? Reconciling environmental benefits with profitable grassland systems. Proceedings of the joint British Grassland Society/British Ecological Society Conference, University of Lancaster, 15-17 April, 2002.

Olper A, Raimondi V, Cavicchioli D, Vigani M (2014) Do CAP payments reduce farm labour migration? A panel data analysis across EU regions. Eur Rev Agric Econ 41 (5): 843-873. doi: 10.1093/erae/jbu002

Pannell DJ (1999) Social and Economic Challenges to the Development of Complex Farming Systems. SEA Working Paper 97/02. Sustainability and Economics in Agriculture.

Pointereau P (2008) Analysis of farmland abandonment and the extent and location of agricultural areas that are actually abandoned or are in risk to be abandoned. EUR-OP.

Primmer E, Karppinen H (2010) Professional judgement in non-industrial private forestry. Forester attitudes and social norms influencing biodiversity conservation. Forest Policy and Economics, 12(2), 136-146.

Rancane S, Makovskis K, Lazdina D, Daugaviete M, Gutmane I, Berzins P (2014) Analysis of economical, social and environmental aspects of agroforestry systems of trees and perennial herbaceous plants. Agronomy Research, 12(2), 589-602.

Renwick A, Jansson T, Verburg PH, Revoredo-Giha C, Britz W, Gocht A, McCracken D (2013) Policy reform and agricultural land abandonment in the EU. Land Use Policy, 30(1), 446-457.

Roellig M, Sutcliffe LME, Sammul M, von Wehrden H, Newig J, Fischer J (2015) Reviving wood-pastures for biodiversity and people: A case study from western Estonia. Ambio (2016) Vol. 45, Issue 2, pp 185195. doi:10.1007/s13280-015-0719-8

Saha SK, Stein TV, Nair PK, Adreu MG (2011) The socioeconomic context of carbon sequestration in agroforestry: a case Study from homegardens of Kerala, India. In: Kumar, B.M. and Nair, P.K., 2011. Carbon Sequestration Potential of Agroforestry Systems. Opportunities and Challenges. Advances in Agroforestry Vol. 8. Springer. 281-298 pp.

Saldana J (2009) The Coding Manual for Qualitative Researchers. Thousand Oaks, California: Sage.

Schläuter A, Koch M (2009) Institutional change in the forest sector: trust and mental models. European Journal of Forest Research, 130(3), 383-393.

Sereke F, Graves A, Dux D, Palma J, Herzog F (2015) Innovative agroecosystem goods and services: key profitability drivers in Swiss agroforestry. Agronomy for Sustainable Development, 35(2), 759 - 770. DOI: 10.1007/s13593-014-0261-2

Sereke F, Dobricki M, Wilkes J, Kaeser A, Graves AR, Szerencsits E, Herzog F (2016) Swiss farmers don't adopt agroforestry because they fear for their reputation. Agroforestry Systems 90:385-394. DOI 10.1007/s10457-015-9861-3.

Suddaby R (2006) From the Editors: What Grounded Theory is Not. Academy of Management Journal. Vol. 49, No. 4, 633-642.

Thierry AD, Snipes SA (2015) Why do farmworkers delay treatment after debilitating injuries? Thematic analysis explains if, when, and why farmworkers were treated for injuries. Am. J. Ind. Med., 58: 178192. doi:10.1002/ajim.22380.

Valdivia C, Gold M, Zabek L, Arbuckle J, Flora C (2009) Human and institutional dimensions of agroforestry. North American Agroforestry: An Integrated Science and Practice 2nd edition, (northamericanag), 339-367.

Varga A, Heim A, Demeter L, Molnár Zs (2016) Rangers bridge the gap: Integration of traditional ecological knowledge related to wood pastures into nature conservation. In: Roué M, Molnár Zs (eds) Indigenous and local knowledge of biodiversity in Europe and Central Asia: Contributions to the IPBES regional assessment of biodiversity and ecosystems services. Paris, UNESCO, pp 78-91. 